\title{
Prerequisites for using solar potential to supply power to consumers in the central ecological area of the Baikal natural territory
}

Nadezhda Khalgaeva*, and Tatyana Tuguzova, Melentiev Energy Systems Institute of Siberian Branch of Russian Academy of Sciences, Irkutsk, Russia

\begin{abstract}
We address the possibility for using solar potential to supply power to consumers in the central ecological zone of the Baikal natural territory, given its special conservation status. Based on an analysis of observations made during expeditions, we revealed the specific features of the location of the settlements and the sites where solar equipment is installed. The considered territory was zoned based on an analysis of the solar potential parameters. The paper presents the priority areas for the solar potential implementation for energy purposes, with a focus on the potential sites for installation of photovoltaic power plants and solar heating systems. Key words: total solar radiation, sunshine duration, annual distribution of direct and diffuse radiation, priority areas of solar potential implementation, effects of solar plants
\end{abstract}

\section{Introduction}

The central ecological area of the Baikal natural territory is about $90,000 \mathrm{~km}^{2}$ and includes Lake Baikal with islands, a water protection zone with its border along the watershed, and specially protected nature conservation areas adjacent to the lake ( 3 wildlife reserves, 2 national parks, 7 sanctuaries). The central ecological area occupies $23 \%$ of the Baikal natural territory. Without the water area of Baikal, $36 \%$ of the territory belongs to the Irkutsk region and 64\% belongs to the Republic of Buryatia.

Most of the zone territory lies in the area with centralized power supply, autonomous plants supply power only to the consumers in hard-to-reach localities.

Tourist centers and populated settlements in the hard-to-reach and off-grid areas use mainly diesel power plants (DPPs) as energy sources, which requires alternative environmentally friendly energy sources. Fuel can often be delivered only by water or air, and only during certain seasons, which entails an increase in the cost of fuel supply to such facilities. Difficulties in the fuel delivery, available renewable energy and a trend towards a reduction in its cost create favorable conditions for the adoption of renewable energy sources and solar energy in particular.

Fig. 1 shows the existing renewable energy sources (RES) revealed during the expeditions on Lake Baikal and its shores.

\footnotetext{
* Corresponding author: khalgaeva@isem.irk.ru
} 


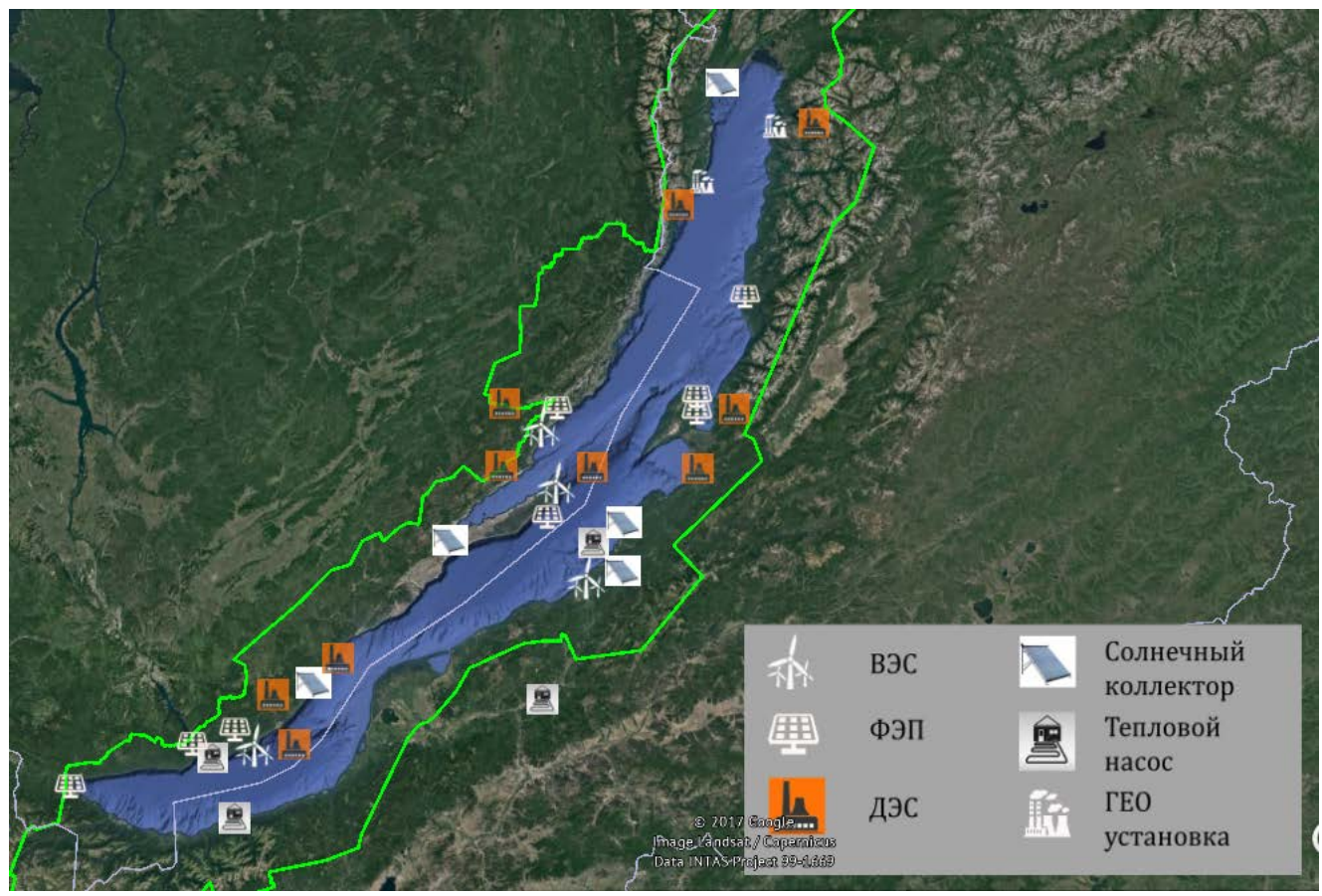

Fig. 1. Renewable energy sources in the central ecological area

The total capacity of the existing renewable energy sources is about $100 \mathrm{~kW}$ (of which $81 \mathrm{~kW}$ is generated by photovoltaic modules in the village of Onguren in the Irkutsk Region).

\section{A resource endowment analysis}

The distribution of the annual solar radiation over the considered territory is of a zonal nature. In the basin of Lake Baikal, its value increases due to the relatively lower cloudiness and higher overall atmosphere transparency. The range of variation in the total solar radiation is from $1100 \mathrm{kWh} / \mathrm{m}^{2}$ in the north to $1300 \mathrm{kWh} / \mathrm{m}^{2}$ in the central part of the considered territory (Fig. 2) [1-4].

Another important characteristic of radiation conditions of this area is the sunshine duration. The main factors that determine it are the day length and the cloudiness conditions. For the central ecological zone, the sunshine duration is 1900-2000 h/year in the north and reaches $2400 \mathrm{~h}$ /year in the southeast. The smallest number of sunshine hours is observed in November-December (50-100 hours), and the largest - in May-June (200300 hours) when during a long daylight there are almost no clouds.

The central part of the Baikal western shore and Olkhon Island are characterized by the largest values of solar potential. The northernmost extremity of the central ecological area shows somewhat smaller values for both the solar radiation and the sunshine duration.

In values of the solar potential indicators, the central ecological area of the Baikal natural territory is not inferior to the southern regions of European Russia. Table 1 shows the values for the total solar radiation and the sunshine duration for the compared territories. 


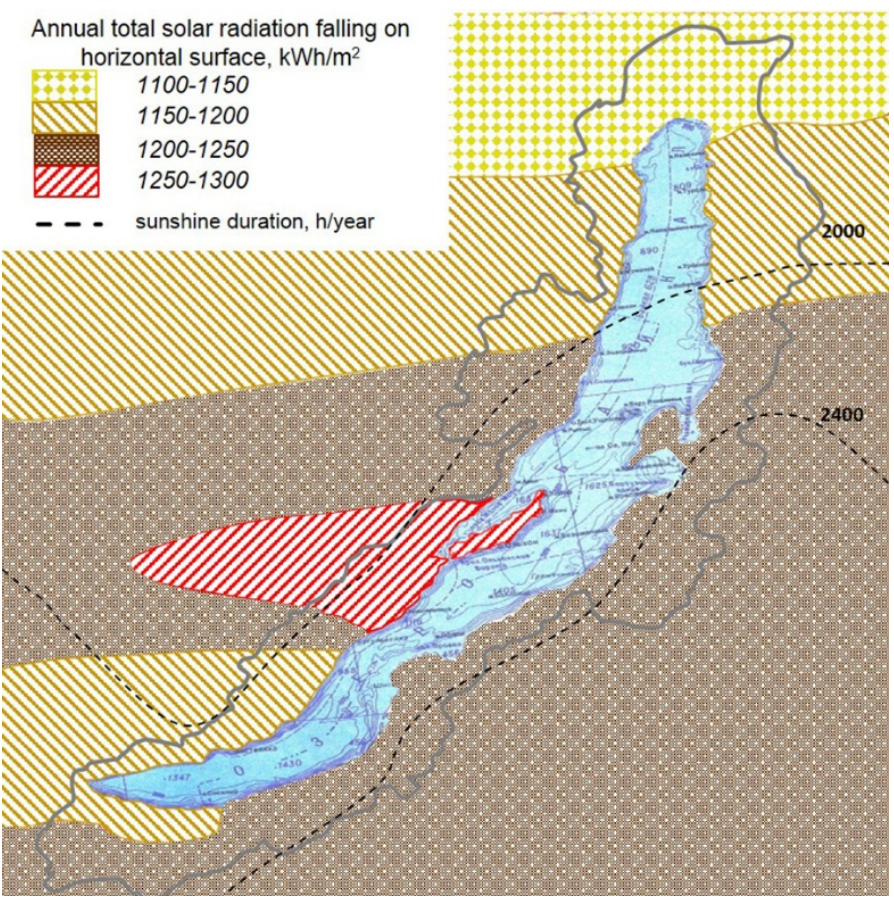

Fig. 2. Territory zoning according to the value of the annual total solar radiation

Table 1. Solar potential indicators for the central ecological area versus southern territories of European Russia

\begin{tabular}{|l|c|c|}
\hline \multicolumn{1}{|c|}{ Settlement, territory } & $\begin{array}{c}\text { Total solar radiation } \\
\text { incident on a horizontal } \\
\text { surface, } \mathbf{k W h} / \mathbf{m}^{\mathbf{2}}\end{array}$ & $\begin{array}{c}\text { Sunshine duration, } \\
\text { h/year }\end{array}$ \\
\hline Settlement of Khuzhir & 1287 & 2277 \\
\hline Settlement of Baikalskoye & 1206 & 1948 \\
\hline Rostov region & $1100-1250$ & over 2000 \\
\hline $\begin{array}{l}\text { Black Sea seaside (Krasnodar } \\
\text { Territory) }\end{array}$ & $1250-1450$ & over 2000 \\
\hline
\end{tabular}

Fig. 3 shows the annual distribution of total solar radiation for two settlements in the central ecological area: Baikalskoye (northern basin) and Khuzhir (central basin).

The annual distribution pattern of solar potential is characterized by a pronounced summer maximum for both the northern and the central parts of the zone. In the considered settlements, the values of solar potential differ greatly only in the summer months.

The share of diffuse radiation in the total solar radiation (which is a sum of direct and diffuse) is rather large (Fig. 4). In summer, the diffuse radiation is about $50 \%$ of the total radiation. In winter, it often exceeds the value of direct radiation, which is typical of the nearshore areas of Lake Baikal (Table 2). 


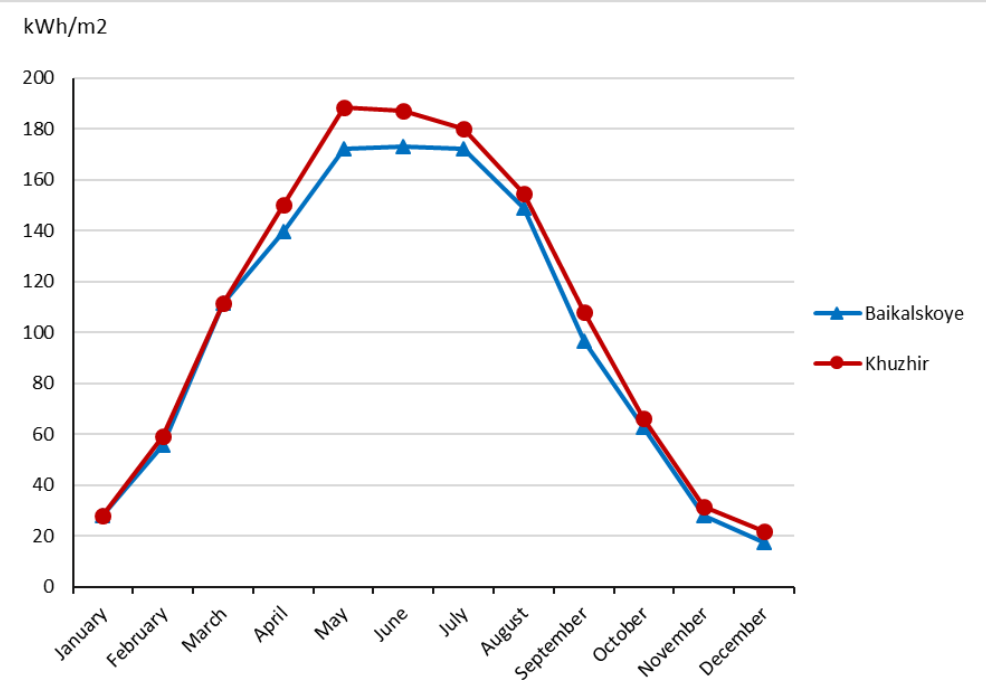

Fig. 3. Annual variation in the total solar radiation incident on a horizontal surface

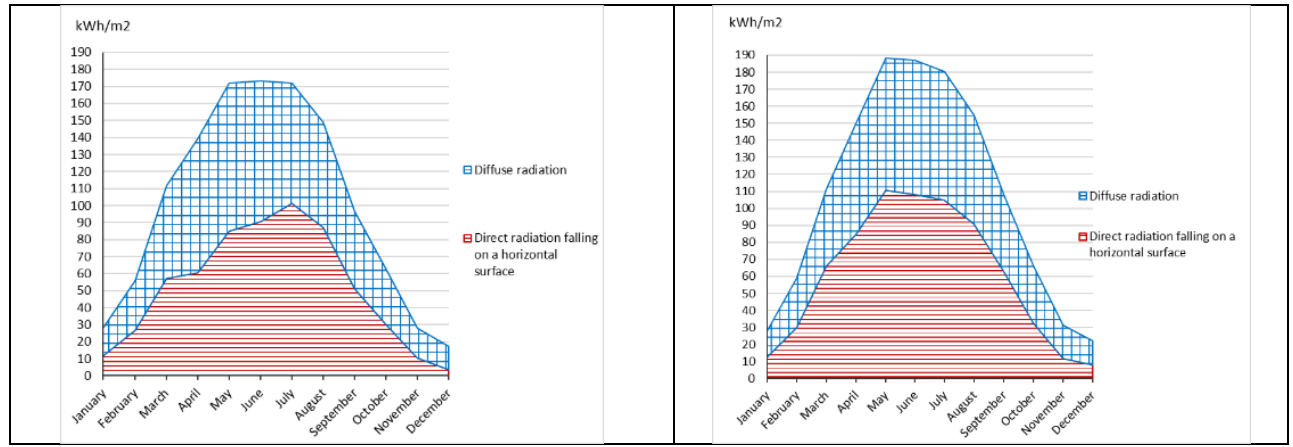

(a)

(b)

Fig. 4. Annual distribution of direct radiation falling on a horizontal surface and diffuse radiation in the settlements of Baikalskoye (a) and Khuzhir (b)

Table 2. Seasonal solar potential indicators for the localities of central ecological area

\begin{tabular}{|l|c|c|c|c|}
\hline \multirow{3}{*}{ Settlement } & \multicolumn{2}{|c|}{ Winter period } & \multicolumn{2}{c|}{ Summer period } \\
\cline { 2 - 5 } & $\begin{array}{c}\text { Direct solar } \\
\text { radiation, } \mathbf{k W h} / \mathbf{m}^{\mathbf{2}}\end{array}$ & $\begin{array}{c}\text { Diffuse solar } \\
\text { radiation, } \\
\mathbf{k W h} / \mathbf{m}^{\mathbf{2}}\end{array}$ & $\begin{array}{c}\text { Direct solar } \\
\text { radiation, } \mathbf{k W h} / \mathbf{m}^{\mathbf{2}}\end{array}$ & $\begin{array}{c}\text { Diffuse solar } \\
\text { radiation, } \\
\mathbf{k W h} / \mathbf{m}^{\mathbf{2}}\end{array}$ \\
\hline Khuzhir & $8-30$ & $14-29$ & $91-108$ & $64-79$ \\
\hline Baikalskoye & $3,5-27$ & $14-29$ & $87-101$ & $62-83$ \\
\hline
\end{tabular}

\section{Priority lines for solar energy application}

The team of researchers from the Laboratory for Energy Supply to Off-grid Consumers (at Melentiev Energy Systems Institute SB RAS) studies potential options for integrated power supply to consumers living in the nearshore area of Lake Baikal with a focus on the integration of conventional energy sources and solar systems. 
The potential lines for the application of solar energy in the central ecological area of the Baikal natural territory are as follows [5-7]:

1) photovoltaic plants for power supply to the off-grid consumers, including populated settlements, weather stations, cordons at reserves, tourist centers located in the hard-toreach localities near Lake Baikal (Khakusy, Kotelnikovsky Cape, Chivyrkuisky Bay, Circum-Baikal Railroad, Small Sea, and the bays behind Listvyanka).

In the nearshore areas of the lake, the $1 \mathrm{~kW}$ photovoltaic plants will allow generating $1500-2000 \mathrm{kWh} /$ year and replacing $0.5-0.6$ ton of diesel fuel. A positive factor in this case is the coincidence between the peak of tourist activity and the maximum solar potential indices in summer.

The Republic of Sakha (Yakutia) is an example of successfully implemented solar power projects, where 20 photovoltaic plants with a total capacity over $1.5 \mathrm{MW}$ are currently in operation in the off-grid area. Some of them are located above the Arctic Circle. According to our estimates, the payback period of the projects does not exceed 10 years.

2) solar collectors and solar heating systems may be used:

- at coal-fired boiler plants to reduce emissions of pollutants, although this measure is not always economically effective, given low coal prices and high cost of solar equipment. According to the recent studies, seasonal single-circuit solar heating systems jointly with fuel oil boilers have the most acceptable payback periods (up to 10 years). A year-round use of dual-circuit solar heating systems requires much more capital investments, which is not justified by the effect obtained;

- to supply hot water to resorts, recreation centers, weather stations, cordons in summertime, given the maximum radiation values at this period.

\section{Implications}

Unfortunately, at present, the use of solar energy in Lake Baikal nearshore areas is of spotty nature. Even the private consumers (including the project of the solar-wind-diesel system in the settlement of Ongureny) that use renewable energy sources, do not have experience and sufficient qualifications to make a techno-economic analysis of the necessary equipment in the initial stage and, consequently, its further effective use.

The use of solar power plants in the central ecological area will reduce environmental pollution and lower the dependence of off-grid consumers on fuel deliveries. In addition, these measures have both economic and social effect, because they will contribute to the improvement in the reliability and quality of power supply and to the increase in the quality of life.

\section{Acknowledgements}

This study was conducted under the Integration Program from Irkutsk Scientific Center of Siberian Branch of the Russian Academy of Sciences, Reg. No. AAAA-A17-117041250054-8

\section{References}

1. O.S. Popel, S.E. Frid, Yu.G. Kolomiets, S.V. Kiseleva, and E.N. Terekhova. Atlas of solar energy resources in Russia. Moscow: Joint Institute for High Temperatures, Russian Academy of Sciences, 81 p. (2010) (in Russian)

2. Atlas of Renewable Energy Resources in Russia: Nauka (Science) Publishers. Moscow: Mendeleyev RChTU, 60 p. (2015) (in Russian) 
3. Reference Book on the USSR Climate. Issue. 22. Irkutsk Region and Western Part of Buryat ASSR. Part 1. Solar Radiation, Radiation Balance, and Sunshine / Ed. N.S. Breken. - Leningrad: Gidrometeoizdat, 72 p. (1966) (in Russian)

4. Reference Book on the USSR Climate. Issue. 23. Buryat Autonomous Soviet Socialist Republic and Chita Region. Part 1. Solar Radiation, Radiation Balance, and Sunshine / Ed. V.I. Zaloznaya, N.G. Postnikova. Leningrad: Gidrometeoizdat, 64 p. (1966) (in Russian)

5. I.Yu. Ivanova, T.F. Tuguzova, and N.A. Khalgaeva. Renewable Energy as One of the Directions of Reducing Anthropogenic Load in Central Environmental Zone of Baikal Natural Territory. Geografiya I Prirodnyye Resursy (Geography and Natural Resources). No. 3, pp. 86-90. DOI: 10.21782 / GiPR0206-1619-2016-3 (86-90) (2016) (in Russian)

6. I.Yu. Ivanova, T.F. Tuguzova, and N.A. Khalgaeva. Increase in Efficiency of Power Supply in the Decentralized Zone with using Renewable Natural Energy Resources by example of Irkutsk Region. Sistemy. Metody. Tekhnologii. (Systems. Methods. Technologies). No. 1 (29), pp. 83-88 (2016) DOI: 10.18324 / 2077-5415-2016-1-8388. (in Russian)

7. O.S. Popel, S.V. Kiseleva, M.O. Morgunova, et al. Using Renewable Energy Sources for Energy Supply to Consumers in the Russian Federation Arctic Zone. Arktika: Ekologiya I Ekonomika (Arctic: Ecology and Economics.), No. 1 (17), pp. 64-69 (2015) (in Russian) 